\title{
Religion and local politics in Southern Europe: a research agenda
}

\author{
Alberta Giorgi $\mathbb{1}^{\mathrm{a}}$ and Xabier Itçaina ${ }^{\mathrm{b}}$

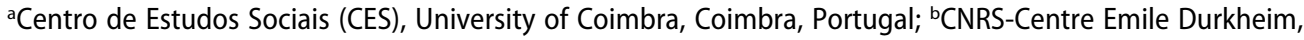 \\ Sciences po Bordeaux, Pessac, France
}

\begin{abstract}
This article brings to a conclusion the series of three special sections published in 2015 and 2016 by Religion, State and Society on 'Religion and local politics in southern Europe'. We set up a research agenda on the interactions between religion and local politics in Southern Europe. In doing so, we focus on the localisation of religion, including religious debates, and on the impact of the recent economic crisis. More specifically, we address the local as a contested concept, the multilevel governance of religion as a scalar opportunity structure - in relation to the transnational dimension of religious actors - the effects of such changes in the welfare landscape and the impact of the economic crisis on the activities and strategies of religious actors in Southern Europe. Our research agenda focuses on the interactions between two main dimensions: the territorial impact of political and economic changes, and the multiscalar schemes of territorial governance.
\end{abstract}

\section{ARTICLE HISTORY}

Received 2 June 2016

Accepted 30 June 2016

\section{KEYWORDS}

Religion; politics; Southern

Europe; governance;

religious diversity

\section{Introduction}

This article brings to a conclusion the series ${ }^{1}$ of three special sections published in 2015 and 2016 by Religion, State and Society on 'Religion and local politics in Southern Europe' (vol. 43, 2; vol. 44, 1; vol. 44, 3). Our ambition is to try to set up a research agenda on the interactions between religion and local politics in Southern Europe. To that end, we will not only refer to both the empirical material taken from this collection of articles but also refer to the broader literature on this topic. In doing so, we address three challenges of contemporary research on religion and politics in Europe.

The first challenge regards the unit of analysis. We believe that there is a Southern European specificity in the interactions between religion and politics. Most Southern European countries, despite being highly secularised, still carry the historical memory of tight bonds between a majority religion and state institutions. These interactions were redefined in the institutional arrangements that were made between the majority churches and the states, either during the democratic transitions from authoritarian regimes (Spain, Portugal, Greece in the 1970s), or by reforming a de facto pro-Catholic 
state (the revision of the concordat in Italy in 1984). Other countries (France and Turkey) had set up earlier models of stricter separation between religions and states. Religious diversity in Southern European countries is mainly related to immigration, which increased especially since the 1990s. Besides their religious profile, these countries also share similar characteristics with respect to other dimensions such as the status of their economy. Indeed, the two major recent crises in Europe, the post-2008 financial and economic crisis and the 2015-2016 refugee crisis, had a severe impact in Southern Europe with consequences on the interactions between religion and politics in each of these countries, particularly in Italy and Greece. Our unit of analysis also includes Turkey, for two reasons. First, sharing similar features (prominence of one religion, low rate of religious diversity, late immigration, economic status), Turkey fits well within the Southern European frame while also broadening the perspective to the eastern edge of the Mediterranean. Second, the form and the history of secularism and secularisation render Turkey quite unique among Southern European countries.

Our second challenge concerns both the secularisation theory and the 'return of religion' thesis. We do not deny the secularisation of Southern Europe and the growing secularism of political authorities. On the contrary, we see the salience of religion and the renewed activism of religious actors as resulting from the process of secularisation and their position in a pluralistic political, social and religious environment. We follow Bode (2003) who, when comparing the Catholic welfare agencies in France and Germany, observed that when the shrinking of the overall influence of Catholicism seemed inevitable, the propensity to engage in social innovation and creative social agency increased within Catholic organisations, together with a growing autonomy of social organisations vis-à-vis their institutional hierarchy. More than a 'return' of a religion that never really left the scene, we rather focus on the changing interactions between religion and politics and on the politicisation of issues that involve religious actors and religious normative positions. In this sense, as Wohlrab-Sahr and Burchardt, we consider 'the entanglements of religion and politics [...] as sites in which the boundaries between religion and secular spheres are negotiated, challenged, and redrawn' (2012, 882). Southern European states, with some exceptions and nuances, are characterised by similar cultures of secularity (Wohlrab-Sahr and Burchardt 2012).

Third, we justify our local focus through its understanding in a multiscalar perspective. Analysing the local interactions between religion and politics does not mean that research should be limited to an ethnographic observation which points out the uniqueness of the case study. Rather, we argue in favour of a multiscalar perspective that embraces the political work conducted simultaneously by religious and political actors around religious and non-religious issues at different scales. By political work, we refer to the struggles that take place around three overlapping processes: problematising issues, converting collective and public responses into policy instruments, and legitimising both problems and instruments (Jullien and Smith 2014).

The local level is where the different regimes and regulations intervene and where social order is produced and reproduced. It is a potential place of innovation. The globalisation process contributed to an increasing role of the local (see, for example, the concept of 'glocalization', Robertson 1995). On the one hand, many policies are being relocated at the local level; on the other hand, the local has gained relevance in symbolic terms. In this picture, a multiscalar perspective also points to the collective 
processes of practical and symbolical negotiations of the meanings and the boundaries of the local.

In this series, we explored four avenues of research, around which this article is structured: (a) the localisation of religious controversies and public debates about religion; (b) the multilevel governance of religious pluralism; (c) the social work undertaken by religious actors in changing welfare regimes and (d) the specific impact of the 2008 economic recession on the local interactions between religion and politics. The article concludes synthetically the main dimensions of this agenda.

\section{The localisation of religious controversies and public debates about religion}

Since the 2000s, many controversies in both the public and the political spheres have increasingly been framed as 'religious issues' involving religious actors and religious values. Schematically, we can identify two sets of issues: the first is related to morality politics (see Engeli, Green-Pedersen, and Larsen 2012), that is, the regulation of life, marriage and death - in other words, the intimate life (Dobbelaere and Pérez-Agote 2015); the second is related to the increase of religious pluralism and diversity in European societies (Vertovec 2007), usually dealt with through the concepts of tolerance (Brown 2008) and multiculturalism (Triandafyllidou 2009), and the regulation of citizenship (Koopmans et al. 2005). In this direction, the issues related to religion interconnect with the debates related to human rights, social cohesion and the governance of the multiple dimensions of diversity in contemporary societies. In other words, they are matters that directly concern democracy. Most religious controversies are described as a dialectical opposition between two sets of irreconcilable values, often related to a supposed war between religious and secularist perspectives. In the U.S.A., these controversies are framed as culture wars, whereas, as Foret notices, the European reality is better described as 'a shifting but strategic use of religion in European politics' (2015, 159). In the European context, the religious factor is often the object of a double reduction: on the one hand, religion is politicised, for example, in the discussions around the foundations of a European identity; on the other hand, mass media often focus only on the conservative and radical aspects of religions (Itçaina 2015a). In the same direction, recent research on the Italian debates concerning religions underlined the role of religious and political actors in structuring the debates in binary 'either-or' terms (Ozzano and Giorgi 2016). In other words, the polarisation of political debates is not a datum - rather, it is the result of a political process in which actors frame and reframe the issues at stake and advocate for their significance in public terms by means of various grammars of generalisation (see Boltanski and Thévenot 1991; Chateauraynaud 2009; Chateauraynaud and Trom 1999; Tilly 2008; Wright Mills 1940). Political controversies and debates concerning religions unfold in discursive arenas characterised by different possibilities of access, opportunities and constraints for different actors. Indeed, even though the issues related to religion may be defined as global issues, the political debates on these topics remain very much a national concern (see Koenig 2007; Koopmans and Statham 2010; Koopmans et al. 2005). Recent research has shown how the existing structures of party conflicts (especially religious cleavages) influence the politicisation and the polarisation of morality issues (Engeli, Green-Pedersen, and Larsen 
2012). At the same time, the public positions of the religions around these controversial issues are deeply related to the power relations at play between religions, and between religions and other social forces (Dobbelaere, Pérez-Agote, and Béraud 2015).

Indeed, the articles included in this series show the relevance of context, focusing on various levels of the 'local' - countries, regions, cities and even neighbourhoods - and localisation with respect to different scales. In this sense, the articles address the local as a relational analytical category. In her study on the Orthodox Church of Greece, Molokotos-Liederman (2016) underlined the complex interactions between national identity and religion, which filtered the impact of the international financial crisis and the Church's responses. Itçaina (2015b) and Griera (2016), on the other hand, focused on regions: Itçaina showed the nuanced effects of the international welfare liberalisation trend in Emilia-Romagna in Italy and the Basque Autonomous Community in Spain; Griera analysed how Catalonia dealt with religious diversity, in light of the complex symbolic positioning of the region with respect to Spain. Giorgi and Polizzi (2015) explored the differences in the repertories of action adopted by a religious organisation in operating at the municipal, regional and country level. Conti (2016) compared and contrasted the debates and policy outcomes concerning the localisation of a mosque in two Italian cities, Bologna and Florence. Finally, Scotto (2016) and Maritato (2016) concentrated on cities: Scotto examined the different visions and action strategies of two religious organisations in the Southern Italian city of Foggia, while Maritato conducted a critical policy ethnographic study on the activities of female preachers in Istanbul. The authors pointed out the various opportunities and constraints of the local contexts analysed by underlining the role of regulatory regimes, configurations of civil society and politics, specific local situations (such as the gangmaster system in Foggia) and the relevance of political entrepreneurs. In this sense, the studies analysed the localisation of global issues and localised practices.

The contributions also highlight a second direction of analysis of the local, in addition to its territorial dimension: the spatial perspective. Indeed, the unfolding of collective practices related to religions in physical places bears a crucial symbolic dimension. In this sense, the controversies over the localisation of the mosques and their distance from the city centre examined by Conti are quite exemplary. The relations between the worship and its setting are a relevant issue also for the female preachers in Istanbul analysed by Maritato in the specific context of the assertive Turkish secularism. The context and the area of the activities of religious actors are significant: in his article, Scotto underlined that the location of the projects (whether in a ghetto or in a specialised setting outside the ghetto) is an important issue for the religious organisations under scrutiny. Besides their symbolic meanings, places and settings are often characterised by specific regimes that influence the very possibility of performing collective activities related to religion, as exemplified by the tax exemption for places of worship and spaces used for charitable activities mentioned by Molokotos-Liederman. While physical space has often been neglected in the sociological and political analyses of religions, in recent years the attention is growing, first, on how space and settings affect urban religious diversity and religiosity, and shape the relationships between religions, and religions and the administration, and, second, on the place-keeping, placemaking and place-seeking strategies of religious actors (see Becci, Burchardt, and Casanova 2013; Becci, Burchardt, and Giorda 2016; Frégosi and Willaime 2001; Giorda 
2015). The articles included in this series contribute to this literature by focusing on the political meanings of places and settings, and on the mutual relationships between local politics and localised religious (or religion-related) practices. In addition, beyond the cities, the contributions in the series focus on a variety of meanings and symbolic constructions of what is 'local', drawing on its relational dimension. In this sense, they are better framed as studies on the 'localisation' of, rather than on the 'local', and studies on the 'localised', rather than on the 'local', religious and political practices and relationships.

\section{Europeanisation and the multilevel governance of religious pluralism}

Localised religions are an object of conflict, as the increasing number of controversies related to the localisation of mosques exemplify (Angelucci, Bombardieri, and Tacchini 2014; O'Miel and Talpin 2013; Triandafyllidou 2006; Triandafyllidou and Gropas 2009). In this series of special sections, Conti explained how the conflicts over the localisation of mosques in Italy have been politicised and polarised by populist parties and defensive social movements with a nationalist profile. In this sense, the local conflicts over the real and symbolic control of the territory are part of a broader picture of the strategic use of religion by political entrepreneurs at the national level. The governance of religious diversity $^{2}$ is indeed a relevant factor for contemporary societies (Bramadat and Koenig 2009) and sometimes an issue of domestic politics and centre-periphery tensions. As Koenig (2007) showed, the process of Europeanisation fostered the convergence of principles for governing religious diversity at the European level, whereas, at the national level, different models of minority inclusion persist ${ }^{3}$ (see also Itçaina 2015a; Koopmans et al. 2005; Modood 2010) and different models for governing religious diversity also emerge within the same country (Maussen 2007). Griera's article, indeed, analysed how the governance of religious diversity was managed by a localised national minority and was appropriated by nationalist parties, from a symbolic and strategic perspective, within the context of Catalonia's claims for autonomy and/or independence. Internal cohesion is a crucial matter to national minorities that seek to preserve their identity: in this sense, religious diversity, related to migration, is an interesting prism through which to analyse the mutual relationships between different types of minority. But internal cohesion is also a matter in state politics. In her contribution, Maritato shows how the introduction of female preachers in Turkey may be interpreted as an attempt of reducing Islam's internal diversity and, at the same time, as a form of state control over religion. As a matter of fact, the institutionalisation of vaize also resulted in women's empowerment within a religious hierarchy which until then had been monopolised by male figures. Maritato touched upon the gender issues related to religion, which raise relevant questions to contemporary societies: what are the relationships between equality, women's rights and religions? A growing literature has deconstructed the monolithic vision of women as subordinated subjects within religious communities and explored the multiple forms of female religious agency in both native and immigrant religions (Aune, Sharma, and Vincett 2008; Bracke 2008; Della Sudda and Malochet 2012; Giorgi and Palmisano 2016; King and Beattie 2004; Mahamood 2005; Rochefort and Sanna 2013). Research on the role of women in religion, and the local interactions between female religious and political agency has allowed further nuancing 
and deepening in the analyses of contemporary relationships between religion and politics in Europe. Even though with some nuances (Ruivo, Francisco, and Gomes 2011), the Europeanisation process contributed to the fragmentation and recomposition of regions and territories (Dehousse 1996). Their symbolic and concrete boundaries and identities have gone through a period of transformation, while territorial differentiation gained relevance in the public sphere. As a matter of fact, the governance of religious diversity presents different profiles in different places and in this sense, Griera underlined the peculiar status of a highly secularised Catalonia with respect to a Catholic Spain. In the same direction, Conti examined the diverse composition of the Muslim community in Florence and Bologna, which has an impact on the communities' strategies. In the same article, the local configurations of both religious and political actors in Italy contributed to the specific outcome of the debates about the localisation of the mosques. Conti's study also underlined the local advantage of Florence, where the availability of regional financial support for participatory processes increased the likelihood of a public discussion on the construction of a local mosque. In the context of relationships between the state and regions, local politics often become the place of experimentation with innovative policies (see also Grigolo 2010). The internal country differences pointed out by Griera and Conti in the composition of religious diversity and the relationships between religion(s) and politics are paralleled by the cross-country regional similarities highlighted by Itçaina's analysis on the Basque Country and EmiliaRomagna.

The process of Europeanisation fostered the devolution of some government tasks to both supra- and infra-national entities: while religious freedom can be considered a global issue, related to human rights, the accommodation of religious diversity involves a variety of fields (such as education, welfare and migration), which have undergone a process of substantial restructuration towards subsidiarity and relocation (see Foret 2015; Bader 2007). The right to establish places of worship, for example, is usually granted at the national level, even though its enactment is often restricted by local zoning laws and municipal regulations. The right to religious education may be part of religious freedom acts or provisions, but it is also related to public policies on education. In this sense, religious diversity is subject to both different legal regimes and regulations, national, regionally and locally, and different policy fields.

In this context, the governance of religious diversity - and related controversies - also underwent a process of relocation: issues related to religions and religious actors are thus dealt with by political actors and policy provisions with different spans of actions and tasks; such issues lie at the interactions between different government levels and legal/policy regimes. In their article, Giorgi and Polizzi analysed how the changes in the Italian state apparatus, resulting from both internal (crisis of the Italian ruling political parties) and external (Europeanisation, devolution and subsidiarisation) factors, affected the actors' political, legal and discursive opportunity structures, opening up new windows of action at different government levels. In this direction, the interactions between different government levels and legal and policy regimes set up contexts characterised by different rules of the game. The contributions by Conti, Giorgi and Polizzi, and Itçaina, clearly show how the different rules of the game, together with the different configurations of political actors, opened up different paths of actions for the actors in the regions under scrutiny. Besides the political context, the scalar discursive opportunity structure 
also proved to be relevant. As Conti underlined, the local media sphere contributed in setting up the arena for the public debates to take place jointly with the national public debates.

As the literature widely discusses (see Kriesi 2008), the Europeanisation process sets up a scalar system of legal, political and discursive opportunities. In this scalar system, actors switch between different venues seeking favourable situations ('venue shopping' Baumgartner and Jones 1993). In recent years, and in relation to the Europeanisation path, scholars pointed out the process of judicialisation of politics (Chicowski 2006, 2007; Hirschl 2008) and religion (Koenig 2015; Koenig and de Galembert 2014; Richardson 2015). Supranational courts, especially the European Court of Human Rights (Fokas 2015), may be an opportunity for local religious actors - especially for religious minorities - to bypass national veto players, encoding their claims in the language of fundamental rights (see also Anagnostou 2014; Annicchino 2013; Guiraudon 2000; Jacquot and Vitale 2014; Paternotte 2008). At the same time, local actions may also foster policy innovation in the governance of religious diversity by means of instruments and experiences that are not specific to the religious field, such as in the case of welfare and migration, in which religious organisations directly contribute to solidarity and social cohesion (Itçaina 2015a).

The relational dimension of the local appears to be a crucial element in the analyses of the relationships between religion and politics. First of all, practices and relations are localised: they take place in specific contexts with different characters with respect to both religions and politics. Second, localised practices are embedded in a complex intertwinement of legal regimes and political, juridical and discursive opportunity structures. Therefore, a thorough analysis of the interactions between religion and politics calls for a multiscalar perspective - from the European Union to the local and vice versa.

\section{Devolution and subsidiarisation: religious actors and the changing welfare landscape}

A third research direction concerns the more discrete and, at first glance, less politicised interactions between religion and local politics in the area of welfare activity undertaken by religious actors. Unlike the visions of a depoliticised charity activity by religious actors, we argue that welfare is one of the sectors where religion and politics are intrinsically embedded (Bäckstrom, Davie, Edgardh, and Pettersson 2010; Van Kersbergen and Manow 2009; Beaumont and Cloke 2012; Belzunegui, Brunet, and Panades 2011; Bode 2003; Frisina 2010).

At the EU level, Foret $(2015,158-196)$ demonstrates that the current marketisation of welfare and the emergence of a neo-liberal kind of welfare state can constitute a threat as well as an opportunity for the different churches. Even if social policies remain in the realm of national competence, EU countries are confronted to the same issues and providing similar answers, a rapprochement reinforced by the Lisbon agenda. Having recorded the historical role of the different churches in the national welfare models, Foret formulates an ambitious hypothesis when he interprets the neoliberal turn of the European welfare systems as testifying a 'historical revenge' (169) taken by Protestantism over Catholicism. The influence of social Catholicism over the 'fathers' who conceived the European project remains present through the principle of 
subsidiarity, which leaves the ultimate responsibility of social policies to the member states, and which emphasises the role of family in matters of social order and solidarity. Foret sees, however, in the European strategy of welfare, with its emphasis on individual responsibility, an implicit shift towards a Protestant (and northern) model. The acknowledgement by the EU of the role of (religious and secular) third sector organisations in the care of marginalised populations illustrates this trend.

Similar assumptions can be found in national and infra-national case studies, including Southern European examples. Here again, a multiscalar approach proves its virtue. In Italy, Andrea Muehlebach (2012) has demonstrated, from an anthropological perspective, how the 'moral neoliberal' approach has become an indispensable tool for the capitalist transformation of welfare. On a basis of fieldwork conducted in Lombardy, Muehlebach shows how the rise of voluntarism in this region has to be understood in the wake of the state's withdrawal from social services. This trend is not specific to the religious third sector: Socialist volunteers are interpreting their unwaged labour as an expression of social solidarity, with Catholic volunteers thinking of their work as expression of charity and love. Ethical citizenry is put to work by the state.

In the same vein, Breda Gray, in her research on the Irish Catholic Church's action in supporting migrants (Gray 2015), shows that the alternative values promoted by the social work of the majority church can correspond to the neo-liberal view which tends to make individuals and communities more responsible for their own welfare. The fact that faith-based organisations (FBOs) became central agents in the integration of migrants in many European countries, including Southern European ones, can be seen as a further illustration of the shift in moral collective responsibilities. This trend relates to the emergence of a new culture of feeling and action which proceeds from a call of empathy, care and compassion that is related, but not reducible, to the intensification of market norms. In Ireland, this change resulted from a historical shift. The Catholic Church used to be a sending church to support Irish emigrants abroad. In the 1990s, the Irish Church became a receiving church and offered social support to the new populations attracted by the economic growth of the Celtic tiger. In the absence of state funding for pro-migrant organisations, private philanthropic foundations developed support services for the migrants. The social organisations of the church found themselves competing in a marketised civil society, trying to assure contractual relations with the state and philanthropic funders. At the same time, philanthropic funding encouraged church organisations to combine an entrepreneurial approach to efficiency and to competitiveness and a moral style insisting on community development, compassion and pastoral care. In Italy, Portugal and Spain, the Catholic Church experienced a similar transformation (from a sending to a receiving church) after the 1980s, which meant a reconversion of its expertise in the context of a changing politicisation of immigration.

All three approaches are based on the same assumption: a de facto congruence between the religious moral style, based on compassion and care, and the neo-liberal orientation of the welfare policies, geared towards individual responsibility and the withdrawal of the state. It is not the place here to discuss the overall validity of this claim. The studies mentioned above have the merit of moving away from any idealised view of the commitment of FBOs in the area of welfare and of relating this commitment 
to a global picture of a changing model of welfare. Several examples from Southern Europe confirm this global reconfiguration.

One should, however, add two nuances to this claim. First, the observation of the local partnerships between religions and policymakers on welfare issues shows that there is a wide variety of configurations, that cannot be reduced to one market-oriented model. Even in a region like Lombardy, characterised by its neo-liberal regional welfare (Giorgi and Polizzi 2015), some local initiatives try to regulate or to moderate the process of welfare marketisation. In the city of Brescia after 2013, the municipality tried to promote a new model of cooperation between third sector organisations in order to avoid the increased competition between these organisations when applying for public funding (procurement contracts). This search for an intermediate model (neither neoliberal subsidiarity nor imposed public interventionism) is itself based on a criticism of the regional policymaking in Lombardy, seen as 'based on the support of the demand, on the basis of a wrong interpretation of the idea of freedom ${ }^{4}$ In this case, the local authority, far from withdrawing, is rather trying to regulate the market of welfare in an area where Catholic social organisations remain very present. The same happened in Lisbon, in the aftermath of the economic crisis, where the local elected politicians, in opposition to the austerity policies adopted by the central government, organised a series of local initiatives to contain the impact of the crisis in the urban context. These initiatives were organised by mobilising civil society associations with Catholic organisations playing a major role (Giorgi and Accornero forthcoming).

A similar observation can be made in the case of France, a southern, or at least Latin, European country which is not included in this series. Even in one of the most secularised societies in Europe, religious organisations, and notably the Secours Catholique (Caritas France) and the ecumenical Diaconat, contribute to the welfare mix in a sort of 'hidden complementarity' (Valasik 2010) with the state. Observing a local branch of the Secours Catholique in the east of France, Wahl (2008) notes that, in this delegation, the Secours only offered assistance to those persons that had been sent to them by the public welfare system. Equally, Itçaina (2015a) observed that in Gironde, the network of the Secours Catholique was modelled according to the map of the social services of the département, and not that of the parishes. In both cases, there is more complementarity between religious institutions and policymakers than a mere retrenchment of the state.

This complementarity is a subject of debate within religious institutions. The frontier becomes blurred between the religious logic of the unconditional gift and the public service logic in terms of rights and entitlement. When sent to the Secours Catholique by welfare workers, people in need might think that they are entitled to social care, which is not necessarily congruent with the religious conception of care. On the other hand, the choice to receive only the persons sent by the public system relieves the Secours from the burden of 'choosing its poor' (Wahl 2008). The issue of complementarity questions the role of religions in social inclusion policy. Even in the birthplace of laïcité, the coconstruction of the welfare mix at the local level reveals a multifaceted intertwining between policymakers and religious organisations with distinct understandings of subsidiarity. But these debates over subsidiarity/substitution can be shelved in the case of social emergencies. In a pragmatic fashion, the responsiveness of FBOs can also pave the way for interdenominational collective action. In Italy, in mid-December 2015, the Catholic community of Sant'Egidio, the Federation of Evangelical Churches and the 
Evangelical Waldensian Church passed an agreement with the Italian state in order to open humanitarian corridors for asylum seekers who fled from Syria, Morocco and Ethiopia. ${ }^{5}$ Obviously, the involvement of religious actors testifies the state's failure in this matter. It also illustrates a multivariate and reciprocal interaction between FBOs and overwhelmed policymakers.

The second nuance comes from the fact that religions themselves are internally divided as regards the approach of welfare. The Catholic Church provides relevant illustrations of this internal pluralism. Muehlebach (2012) and Giorgi and Polizzi (2015) have demonstrated that, in the case of Lombardy, the neo-liberal approach of subsidiarity has been largely conveyed by Catholic movements, such as Communion and Liberation. Alternative visions are expressed by other Catholic organisations, such as Caritas, or organisations related to religious orders, which promote a less liberal approach to subsidiarity and call for the responsibility of the public authorities. Some of these organisations will mobilise alongside the anti-austerity actions in Spain or in Portugal (Itçaina 2015a, 2015b). This internal pluralism has itself a long history, which, we believe, can be elucidated by local and multiscalar observations. Again in the Catholic context, Rétière (2002) has proposed a longitudinal history of confessional care in the French city of Nantes, where he shows divergent perspectives between the Société SaintVincent de Paul, historically related to the local upper classes and promoting traditional charity, and the Secours Catholique, more oriented towards solidarity. Such internal divergences became obvious in the end of the 1990s in many French cities when Catholic organisations had to decide if they supported specific mobilisations, such as supporting the sans papiers (illegal migrants), especially when these groups staged hunger strikes in churches.

In this series, Scotto (2016) has illustrated how the migrant seasonal workers in Foggia generated an internal debate between two third sector organisations. The first one, the Scalabrians, is a Catholic religious order working with migrants since the end of the nineteenth century. The second one is the Libera association, whose purpose is the promotion of legality and the struggle against the Mafia. Although being nonconfessional and related to left-wing social movements, Libera was nonetheless founded by a Catholic priest and shares many values with those sectors of the Catholic Church that are more committed to social issues. In Foggia, both associations had to face a situation of immigrant ghettoes controlled by the gangmaster system acting as an illegal intermediary in the job market. Non-profit organisations were confronted with a dilemma: should they assist immigrants within the ghettoes, thus reinforcing indirectly the very existence of these ghettoes, or should they rather commit themselves in the fight against the gangmaster system? The choices made by the organisations revealed different conceptions of their charitable and transformative missions.

These two nuances do not invalidate the thesis of the contribution of religious institutions to a silent and ongoing process of neo-liberalisation of welfare. We simply argue that paying attention to local configurations helps to add some caveats to this general statement, given the plurality of interpretations of subsidiarity and the internal pluralism of religions with respect to welfare.

\section{Religion and economic recession: what can we learn from the local?}

A careful approach is more than necessary in the context of the major economic crisis that affected Southern European countries after 2008. In line with ongoing research on 
this aspect, ${ }^{6}$ we suggest a fourth research direction that would consist in analysing the consequences of the post-2008 economic crisis in Southern Europe on the religionpolitics relations. A multiscalar approach is required in order to understand these transformations. The economic crisis is a perfect example of the intertwining of global, meso- and micro-local factors. In this section, we propose a research agenda based on three assumptions, relying mostly on observations made in Greece (MolokotosLiederman 2016) and in Spain (Itçaina 2015a, forthcoming), the two Southern European countries most hit by the crisis. Despite national specificities, this agenda is also valid for Italy and Portugal.

On the one hand, the economic recession is an opportunity for the majority (and minority) religions to publicise their discourses on values, tailored to specific circumstances. Churches are calling for the moralisation of the economy and politics, linking it with the recurrent struggles of the church on morality policy. In Spain, the economic recession was an opportunity for the Catholic Church to renew a three-fold discourse. First, the Spanish Episcopal Conference (SEC) expressed a strong critique of unregulated capitalism, the retreat of the welfare state and political corruption. The analysis of the causes of the recession extends beyond the purely economic factors. The SEC sees a 'loss of moral values ${ }^{7}$ and highlights the negative consequences of corruption, greed and the lack of control of financial institutions in the context of economic globalisation. To these socio-economic causes is added the strictly religious criticism of man's focus on material well-being without moral or religious values. Finally, the recession provided the opportunity for making the connection between two arguments: linking ethical-moral issues and family policies with a moral interpretation of Spanish territorial and nationalist tensions by branding centrifugal political tendencies as 'territorial selfishness'. A similar normative offensive of the Catholic Church could be seen in Italy and Portugal, even if it was less confrontational.

Second, in addition to taking a position, churches are responding to the recession through a programme of effective social work aiming to offset the failures of the market and public authorities. This social work leads the churches to undertake forms of political advocacy, sometimes alongside anti-austerity or pro-migrant social movements. Molokotos-Liederman (2016) explores the impact of the economic crisis on the Orthodox Church of Greece (OCG). The OCG played a crucial role as a welfare provider by default during the major economic crisis that affected Greece after 2008. The OCG was very present in the welfare sector far before the crisis erupted, but the dramatic increase of the economic difficulties and the failure of the Greek state gave a new visibility to the welfare work of the OCG. When state welfare services proved to be an insufficient safety net and the economic pressures from the crisis on the family became too great, the church turned into a critical resource and ended up assuming the role of a 'second family'. A similar process took place in Portugal, where the activities promoted by the Catholic Catholic organisations (especially Caritas) gained increasing importance in the aftermath of the economic crisis. Indeed, the actions and programmes were expanded and diversified, and the voices of organisations related to the Catholic Church were respected and made more relevant with regard to social and welfare issues. Since the crisis, Catholic local groups have been involved, for example, in monitoring the effects of the crisis and in the elaboration and implementation of local policies and plans (Accornero 2015; Giorgi and Accornero forthcoming). 
In Southern Europe as a whole, the recession has revealed the shortcomings of the welfare state and the role of civil society organisations as social buffers. The Mediterranean welfare model has long been characterised by the importance of Catholic agencies in providing support to families and poor people (Minas et al. 2014). In Spain (Moreno 2006, 74), and also in Portugal and in Italy, the strengthening of the welfare state over the last few decades relegated the Church's charitable activity to a substantial yet complementary role. At the same time, the Southern European welfare has undergone a process of liberalisation, with private stakeholders starting to provide social services. The outsourcing of many social services to the third sector has led observers to speak of 'welfare privatization' (77). Thus, the welfare mix has witnessed the development of a marketisation of the social care sector, notably in Spain (Montagut 2011). The public sector has introduced the methods of the market sector to the ways it implements its social policies. This has had the effect of reinforcing the involvement of the private for-profit sector in the outsourcing of social services. Thus, paradoxically it was the liberalisation of welfare that brought the religious organisations back to the front line, this time as third sector organisations.

Again, the role of the Catholic third sector in this crisis of welfare should be seen as a multiscalar one. In Spain, owing to an asymmetric decentralisation, numerous regional welfare regimes can be distinguished (Gallego and Subirats 2011). Given their institutional and fiscal capacity, the Basque and Navarre regional welfare schemes stand out owing to the substantial presence of public stakeholders in social policies. In these regions, public and 'private social' agencies developed a partnership that undoubtedly helped mitigate the impact of the 2008 recession compared to other Spanish regions. Local welfare regimes also helped develop and influence the role of the Catholic third sector in matters pertaining to local governance. This also led to different approaches in the marketisation of welfare according to regions, provinces and even cities, as evidenced by Elander, Davelaar and Walliser (2012) who contrast an inclusive local welfare regime (with the participation of the third sector) in Barcelona and a market-led regime in Madrid. A similar pattern of differentiation in the local approaches to the marketisation of welfare can be found in Italy (Bifulco 2015). Starting from the 1990s, and especially in the early 2000s, health and social services in Italy were decentralised at the level of regions and cities. Besides national standards of care, each region became free to promote its specific model of welfare provision, which ranges from a market-driven welfare system in Lombardy to a more administration-driven model in Tuscany (Giorgi and Polizzi 2015).

The third impact of the recession in Southern Europe concerns the churches themselves by revealing old public debates on church-state relations and on the institutional benefits of the churches. In Greece, the OCG was itself very much affected by the crisis, as being institutionally related to the Greek state apparatus (Molokotos-Liederman 2016). The Church tried to compensate for the decreasing public resources by developing its real estate assets, in order to maximise its revenue. The OCG also called upon the support of the Greek diaspora and of the transnational Orthodox networks. As a backlash effect, the crisis also brought to the fore a public controversy about the Church's property and finances. Paradoxically, the crisis simultaneously increased the social role of the OCG while also challenging its social and political legitimacy and financial privileges. In Spain, the recession also had a two-fold 
backlash on the Catholic Church. On the one hand, the recession affected the financial situation of the church, especially donations. Budget cuts affected church organisations that relied on public subsidies and public tenders. As a result, at the forefront of the fight against exclusion, the social organisations of the church have themselves been financially weakened by the recession. More broadly speaking, the recession led to a major institutional crisis affecting not only the legitimacy of the Church but also other major Spanish institutions. As a result, public attention has focused on the economic and institutional 'privileges' of the Church, not only in Spain but also in Italy and Portugal. In 2011, for instance, the Association of Portuguese Atheists asked the Portuguese government to cancel the Church's tax exemptions because of the crisis. Various controversies triggered by the recession concerned the majority churches. The first one, which first erupted in Italy in 2015 and then in Spain, concerned the taxation of the Church's assets. This controversy opened a broader debate about the church-state institutional arrangements emerging from the democratic transition in Spain and from the 1984 revision of the concordat in Italy. Again, there is a need for local case studies to contribute to the emerging literature on the 'ethnography of austerity' (Knight and Stewart 2016).

\section{Conclusion}

In this article, we have sketched a research agenda on religion and local politics in Southern Europe, only partially covered by this collection of articles. Our research agenda focuses on the interactions between the territorial impact of political and economic changes, and the multiscalar schemes of territorial governance. First, the interactions between religion and local politics will vary according to the differentiated territorial impact of certain political and economic factors. The differentiated waves of immigration will have an impact on the territorial distribution of religious diversity. In Portugal, where immigration is concentrated mostly in the Lisbon area, religious diversity remains very limited outside the metropolitan area. Conversely, a city like Barcelona has become an experimental field in terms of both the policies of religious accommodation and immigrant policies. The political and policymaking roles of religious actors in a number of policy fields (welfare, migration, education) depend also on the type of territorial welfare regime, which entails on the religious side different approaches of subsidiarity. Different territorial welfare regimes also have impact on the status and the opportunity structure of religious minorities connected to migration. Beyond the welfare sector, the level of territorial decentralisation and/or devolution of policies in each country is a determining factor in understanding the political impact of religious actors. In some instances, as in the case of places of worship in Italy, localised rights can emerge and be institutionalised. Given the combined effects of globalisation and devolution, European states have less control on a number of policy fields, for example, economy, which might explain their focus on other fields, such as identity and morality politics (Koopmans et al. 2005), or on the control of illegal migration fluxes, which are precisely the sectors of intervention of the churches. Finally, the economic recession, despite its adverse effects in Southern Europe as a whole, had a different impact not only on states but also on regions by accentuating already existing territorial cleavages like the north/south divide in Spain, Italy and Portugal. 
Second, we are making the case in favour of a multiscalar analysis of the interactions between religion and politics. The municipal level is relevant for most of the issues addressed here. Even 'moral' issues can be dealt with at the municipal level. For example, in Italy with respect to the living will, some municipalities organised the 'municipal registers for end of life decisions', a decision which inevitably triggered debates on religious and ethical issues, both locally and nationally. Social movements can also choose to mobilise at the local level in order to pressure the government. This strategy is also used by offensive and defensive social movements related to 'morality politics', as, for instance, the lesbian, gay, bisexual and transgender (LGBT) movement in France, Italy, Belgium and Spain (Ozzano and Giorgi 2016; Paternotte 2008) or, on the other side, the Manif pour tous (Béraud and Portier 2015). The municipal level is also relevant in aspects relating to the governance of religious diversity, notably concerning urban planning and places of worship, and some welfare services. The impact of the economic recession can be measured at the local level, notably through the welfare activity of the churches.

Regions, and in some cases provinces or départements, are active levels of governance, depending on the degree of devolution. On morality politics, for instance, some Italian regions took a position against projects supporting gender equality in school. Regions can also be active on the governance of religious diversity, an issue which can be, as evidenced in Catalonia, directly or indirectly seized by regional authorities. Even if they do not have formal competencies in the regulation of religion, regions can de facto deal with religious issues by 'translating' these public problems according to their own set of competences in cultural policy, welfare and health policy, local development, or even, as in Spain, language policy, and, as in Italy, security. This is particularly true for highly decentralised countries like Italy and Spain.

Focusing on the subnational scale does not mean that the national and supranational level should be neglected. On the contrary, it is in the constant multiscalar political work conducted by the religious and political actors that interactions are elaborated. States remain sovereign rulers of morality politics, the governance of religious diversity, welfare regimes and the regulation of economic recession. This multiscalar institutional system is completed by the EU, where a great deal of political work on morality politics, religious diversity, welfare regimes and economic policies is conducted by religious and political actors. Majority religions that are subject to a specific regime of regulation at the national level - such as the French regime of laïcité - can use the EU to establish transnational coalitions with representatives of religions coming from more flexible church-state models. Minority religions can also use EU institutions to voice their concerns and to translate them through the grammar of the fundamental rights. In this sense, the multiscalar environment has also an important symbolic function, offering the possibility of redefining and renegotiating what are the boundaries of the 'imagined community' of reference in different venues and arenas.

To these interactions should be added the local effects of the increasing transnational religious networks. When promoting new forms of religious belonging, based on religious and ideological affinities, these purely religious networks challenge the traditional forms of belonging based on territorial and cultural anchorings. According to Roy (2008), this tendency is shared by the main religious traditions. The 'deterritorialization of the 
local' (298) renders even more complex the multiscalar and permanent reinvention of the interactions between religion and politics in Southern Europe.

The recent Brexit referendum brought to the fore the question of how different versions of 'the local' are developed and formulated. On the one hand, the Brexit campaign, promoting territorially based social solidarities, focused on the tensions between the U.K. and the rest of the world, and between 'the British' and 'others'. Immigration, employment and welfare were some of the central underlying tenets of the campaign. In this sense, the views that were voiced addressed both a horizontal (the other European countries) and a scalar (the EU) dimension. On the other hand, 'Bremain' campaigners (and the 'Bregret' aftermath) underlined the multiple interconnections and the scalar relations of the EU and the U.K., promoting international social cohesion and the symbolic relevance of officially recognising relations that are already in place. Moreover, multiple analyses after the vote clearly showed how class, social status and geographic location influenced positions on the topic, pointing out the urgent necessity for a more balanced socio-economic development. The U.K. religious leaders overwhelmingly supported the 'remain' option, underlining that 'so many of the challenges we face today can only be addressed in a European, and indeed a global, context: combating poverty in the developing world, confronting climate change and providing the stability that is essential to tackling the current migration crisis' (The Guardian, May 29, 2016). ${ }^{8}$

\section{Notes}

1. The series includes the following articles: Religion, State and Society 43(2): X. Itçaina, 'The crisis as a constrained opportunity? Catholic organisations and territorial welfare in the Basque Country and Emilia-Romagna.' (118-132); A. Giorgi and E. Polizzi 'Communion and Liberation: A Catholic movement in a multilevel governance perspective.' (133-149); Religion, State and Society 44(1): M. Griera 'The governance of religious diversity in stateless nations: The case of Catalonia' (13-31); L. Molokotos-Liederman 'The impact of the crisis on the Orthodox Church of Greece: A moment of challenge and opportunity?' (32-50); and A. Scotto 'Focusing on the emergencies or on their roots? The role of nonprofit organisations in immigration policymaking in Italy.' (51-64). Religion, State and Society 44(3) (in this issue): B. Conti 'Islam as a new social actor in Italian cities: Between inclusion and separation'; and C. Maritato, 'Reassessing Women, Religion and the Turkish Secular State in the light of the Professional Female Preachers (Vaizeler)'s Everyday Activities in Istanbul'.

2. On the concept of 'governance of religious diversity' and its difference from the 'government' and 'management' of religious diversity, see Bader (2009).

3. Koenig argues that the institutionalisation of the governance of religious diversity at the European level also has the almost paradoxical effect of enhancing national models of governance of religions/religious diversity (Koenig 2007).

4. 'Social innovation: La sfida di Brescia: saremo la prima città "zero bandi"' [Social innovation: The challenge of Brescia: we will be the first city with 'zero public tenders'] Vita, October $2013<$ http://www.assifero.org/oggetti/5271.pdf> (our translation).

5. 'Progetto pilota. Siria: Arrivati a Roma 93 profughi' [Pilot project. Syria: 93 refugees arrive in Rome], L'Avvenire, May 13, 2016.

6. See the forthcoming special issue of the Journal of Contemporary Religion on 'Majority Churches and the Crisis in Southern Europe', coordinated by Lina Molokotos-Liederman.

7. 'Declaración ante la crisis moral y económica' [A declaration on the moral and economic crisis], XCIV Asamblea Plenaria de la Conferencia Episcopal Española, Madrid, November 27, 2009. p. 1. Translated from Spanish. 
8. The Guardian, 'Brexit would jeopardise peace in Europe, warn religious leaders', Toby Helm and Mark Townsend, May 29, 2016.

\section{Acknowledgements}

The authors would like to thank Philip Walters and Lina Molokotos-Liederman for coordinating the series of special issues and for their work in language editing. The authors would also like to thank all the anonymous referees for their invaluable comments. Alberta wishes to thank the research group GRASSROOTSMOBILISE, http://grassrootsmobilise.eu/.

\section{Disclosure statement}

No potential conflict of interest was reported by the authors.

\section{Funding}

Alberta Giorgi's work was supported by Fundação para a Ciência e a Tecnologia under Grant SFRH/BPD/77552/2011. Xabier Itçaina benefitted from the support of the Marie Curie IntraEuropean Fellowship (2012-2013), European Commission.

\section{Notes on contributors}

Alberta Giorgi is a researcher at the Centro de Estudos Sociais, University of Coimbra and an associate member of GSRL (CNRS). She also collaborates with the project GRASSROOTSMOBILISE. Her research interests include political secularism and secularisation, religious associations and political participation. Her recent publications include 'European Culture Wars and the Italian Case: Which Side Are You On?', with L. Ozzano, Routledge 2016; and the guest editorship of the special issue 'Gendering the Secular: Interventions in Politics, Philosophy and Movements', Religion and Gender, 5(2), with T. Toldy.

Xabier Itçaina is a CNRS research fellow at Sciences Po Bordeaux and a former Marie Curie Fellow (2012-2013) at the European University Institute, Florence. His research interests are Catholicism and territorial politics in Southern Europe, the territorial dynamics of social economy, and identity politics. His publications include: 'Between logics of deliberation and appropriateness: the discourse and practices of the Catholic Church over the Basque issue', Critical Policy Studies, 7(3) (2013); 'Between hospitality and competition: the Catholic Church and immigration in Spain' (with F. Burchianti), in A. Hennig and J. Haynes (eds.), Religious Actors in the Public Sphere (Routledge, 2011); and Politics of Religion in Western Europe: Modernities in Conflict? (co-edited with F. Foret) (Routledge, 2011).

\section{ORCID}

Alberta Giorgi (D) http://orcid.org/0000-0003-2188-2682

\section{References}

Accornero, G. 2015. "Le città e la crisi. Il caso di Lisbona." [Cities and the Crisis. The Case of Lisbon]. In Le città e la crisi [Cities and the Crisis], edited by F. De Nardis, 207-242. Roma: Bordeaux edizioni. 
Anagnostou, D. 2014. "Law and Rights' Claiming on Behalf of Minorities in the Multi-Level European System." In Rights in Pursuit of Social Change. Legal Mobilisation in the Multi-Level European System, edited by D. Anagnostou, 1-24. Oxford: Hart Publishing.

Angelucci, A., M. Bombardieri, and D. Tacchini, ed. 2014. Islam e Integrazione in Italia [Islam and Integration in Italy]. Venezia: Marsilio.

Annicchino, P. 2013. "Religion and EU Institutions." Ecclesiastical Law Journal 15: 326-331. doi:10.1017/S0956618X13000458.

Aune, K., S. Sharma, and G. Vincett, eds. 2008. Women and Religion in the West: Challenging Secularization. Aldershot: Ashgate.

Bäckstrom, A., G. Davie, N. Edgardh, and P. Pettersson eds. 2010. Welfare and Religion in 21st Century Europe: Volume 1: Configuring the Connections. Farnham: Ashgate.

Bader, V. 2007. Secularism or Democracy? Associational Governance of Religious Diversity. Amsterdam: Amsterdam University Press.

Bader, V. 2009. "The Governance of Religious Diversity: Theory, Research and Practice." In International Migration and the Governance of Religious Diversity, edited by P. Bradamat, and M. Koenig, 29-58. Montreal: McGill-Queen's University Press.

Baumgartner, F. R., and B. D. Jones. 1993. Agendas and Instability in American Politics. Chicago: University of Chicago Press.

Beaumont, J., and P. Cloke, eds. 2012. Faith-Based Organisations and Exclusion in European Cities. Bristol: Policy Press.

Becci, I., M. Burchardt, and J. Casanova, eds. 2013. Topographies of Faith: Religion in Urban Spaces. Leiden: Brill.

Becci, I., M. Burchardt, and M. Giorda. 2016. "Religious Super-Diversity and Spatial Strategies in Two European Cities." Current Sociology. Advance online publication. doi:10.1177/0011392116632030.

Belzunegui, A., I. Brunet, and C. Panades. 2011. L'acció social de l'Església. Estudi sobre l'acció social de l'Església en l'àmbit territorial de l'Arxidiòcesi de Tarragona [The Social Work of the Church. A Study on the Social Work of the Church in the Archdiocese of Tarragona]. Tarragona: Anàlisi Social i Administrativa/Universitat Rovira i Virgili.

Béraud, C., and P. Portier, eds. 2015. Métamorphoses catholiques. Acteurs, enjeux et mobilisations depuis le mariage pour tous [Catholic Metamorphoses. Actors, Challenges and Mobilizations after the Marriage for All]. Paris: Editions de la MSH.

Bifulco, L. 2015. Il welfare locale. Roma: Carocci.

Bode, I. 2003. "A New Agenda for European Charity: Catholic Welfare and Organizational Change in France and Germany." VOLUNTAS: International Journal of Voluntary and Nonprofit Organizations 14 (2): 205-225. doi:10.1023/A:1023952128109.

Boltanski, L., and L. Thévenot. 1991. De la justification. Paris: Gallimard. (English edition: (2006) On Justification: Economies of Worth. Princeton: Princeton University Press.)

Bracke, S. 2008. "Conjugating the Modern/Religious, Conceptualizing Female Religious Agency. Contours of a 'Post-Secular' Conjuncture." Theory, Culture \& Society 25 (6): 51-67. doi:10.1177/ 0263276408095544.

Bramadat, P., and M. Koenig, eds. 2009. International Migration and the Governance of Religious Diversity. Montreal: McGill-Queen's University Press.

Brown, W. 2008. Regulating Aversion: Tolerance in the Age of Identity and Empire. Princeton: Princeton University Press.

Chateauraynaud, F. 2009. "Public Controversies and the Pragmatics of Protest. Toward a Ballistics of Collective Action." http://gspr.ehess.free.fr/documents/FCPublic\%20controversies\%20and\% 20the\%20Pragmatics\%20of\%20Protest.pdf.

Chateauraynaud, F., and D. Trom. 1999. Les sombres précurseurs. Une sociologie pragmatique de l'alerte et du risque [The Dark Precursors. A Pragmatic Sociology of Risk and Alert]. Paris: Editions de I'EHESS.

Cichowski R. A. 2006. "Introduction. Courts, Democracy and Governance." Comparative Political Studies 39 (3): 3-21. doi:10.1177/0010414005283217.

Cichowski R. A. 2007. The European Court and Civil Society. Litigation, Mobilization and Governance. Cambridge: Cambridge University Press. 
Conti, B. 2016. "Islam as a New Social Actor in Italian Cities: Between Inclusion and Separation." Religion, State and Society 44 (3). doi:10.1080/09637494.2016.1220770.

Dehousse, R. 1996. "Les Etats et I'Union Européenne, les Effets de I'Intégration." [The States and the European Union, the Effects of Integration]. In La Recomposition de l'Etat en Europe [The Recomposition of the State in Europe], edited by V. Wright, and S. Cassese, 55-70. Paris: La Découverte.

Della Sudda, M., and G. Malochet. 2012. "Pouvoirs, genre et religions." [Powers, Gender and Religions]. Travail, genre et sociétés 27 (1): 29-32. doi:10.3917/tgs.027.0029.

Dobbelaere, K., and A. Pérez-Agote, eds. 2015. The Intimate. Polity and the Catholic Church. Laws about Life, Death and the Family in So-called Catholic Countries. Leuven: Leuven University Press.

Dobbelaere, K., A. Pérez-Agote, and C. Béraud. 2015. "Comparative Synthesis." In The Intimate, edited by K. Dobbelaere, and A. Pérez-Agote, 199-221. Leuven: Leuven University Press.

Elander, I., M. Davelaar, and A. Walliser. 2012. "Faith-Based Organisations, Urban Governance and Welfare State Retrenchment." In Faith-Based Organisations and Exclusion in European Cities, edited by J. Beaumont, and P. Cloke, 81-103. Bristol: Policy Press.

Engeli, I., C. Green-Pedersen, and L. T. Larsen. 2012. Morality Politics in Western Europe. Parties, Agendas, and Policy Choices. Basingstoke: Palgrave MacMillan.

Fokas, E. 2015. "Directions in Religious Pluralism in Europe: Mobilizations in the Shadow of European Court of Human Rights Religious Freedom Jurisprudence." Oxford Journal of Law and Religion 4 (1): 54-74. doi:10.1093/ojlr/rwu065.

Foret, F. 2015. Religion and Politics in the European Union. The Secular Canopy. Cambridge: Cambridge University Press.

Frégosi, F., and J.-P. Willaime. 2001. Le Religieux dans la commune: régulations locales du pluralisme religieux en France [The Religious in Common: Local Regulations of Religious Pluralism in France]. Geneva: Labor et Fides.

Frisina, A. 2010. "What Kind of Church? What Kind of Welfare? Conflicting Views in the Italian Case." In Welfare and Religion in 21st Century Europe: Volume 1, edited by A. Bäckstrom, G. Davie, N. Edgardh, and P. Pettersson, 147-166. Farnham: Ashgate.

Gallego, R. and J. Subirats. 2011. "Regional welfare regimes and multi-level governance." In The Spanish welfare state in European context, edited by A.M. Guillén, and M. León, 97-118. Farnham: Ashgate.

Giorda, M. 2015. "I luoghi religiosi a Torino. Le religioni nei contesti urbani contemporanei." [Religious Places in Turin. Religions in Contemporary Urban Contexts]. Quaderni di Diritto $e$ Politica Ecclesiastica, vol. 2/2015. 337-356. doi:10.1440/81259.

Giorgi, A., and G. Accornero. forthcoming. "The Catholic Church and the Crisis: The Case of Portugal." Journal of Contemporary Religion.

Giorgi, A., and S. Palmisano, eds. 2016. D come Donne, D come. Milano: Mimesis.

Giorgi, A., and E. Polizzi. 2015. "Communion and Liberation: A Catholic Movement in a Multilevel Governance Perspective." Religion, State and Society 43 (2): 133-149. doi:10.1080/ 09637494.2015.1062600.

Gray, B. 2015. "The Politics of Migration, Church and State: A Case-Study of the Catholic Church in Ireland." International Migration Review. Advance online publication. doi:10.1111/imre.12165.

Griera, M. 2016. "The Governance of Religious Diversity in Stateless Nations: The Case of Catalonia." Religion, State and Society 44 (1): 13-31. doi:10.1080/09637494.2016.1171576.

Grigolo, M. 2010. "Human Rights and Cities: The Barcelona Office for Non-Discrimination and Its Work for Migrants." The International Journal of Human Rights 14 (6): 896-914. doi:10.1080/ 13642987.2010.512134.

Guiraudon, V. 2000. "European Courts and Foreigners' Rights: A Comparative Study of Norms Diffusion." International Migration Review 34 (4): 1088-1125. doi:10.2307/2675976.

Hirschl, R. 2008. "The Judicialization of Politics." In Oxford Handbook of Law and Politics, edited by K. E. Whittington, D. Kelemen, and G. A. Caldeira, 119-141. Oxford: Oxford University Press.

Itçaina, X. 2015a. Les politiques territoriales du religieux. Médiations catholiques en Europe du Sud [The Territorial Politics of Religion. Catholic Mediations in Southern Europe]. Habilitation à 
Diriger les Recherches. Vol. 2. Bordeaux: Centre Émile Durkheim, Sciences Po Bordeaux, Université de Bordeaux.

Itçaina, X. 2015b. "The Crisis as a Constrained Opportunity? Catholic Organisations and Territorial Welfare in the Basque Country and Emilia-Romagna." Religion, State and Society 43 (2): 118-132. doi:10.1080/09637494.2015.1059656.

Itçaina, X. forthcoming. "The Spanish Catholic Church and the Economic Recession: Rival Legitimacies at Stake." Journal of Contemporary Religion.

Jacquot, S., and T. Vitale. 2014. "Law as Weapon of the Weak? A Comparative Analysis of Legal Mobilization by Roma and Women's Groups at the European Level." Journal of European Public Policy 21 (4): 587-604. doi:10.1080/13501763.2014.887138.

Jullien, B., and A. Smith, eds. 2014. The EU's Government of Industries: Markets, Institutions and Politics. Abingdon: Routledge.

King, U., and T. Beattie, eds. 2004. Religion, Gender and Diversity: Cross-Cultural Perspectives. London: Continuum.

Knight, D., and C. Stewart. 2016. “Ethnographies of Austerity: Temporality, Crisis and Affect in Southern Europe." History and Anthropology 27 (1): 1-18. doi:10.1080/02757206.2015.1114480.

Koenig, M. 2007. "Europeanising the Governance of Religious Diversity: An Institutionalist Account of Muslim Struggles for Public Recognition." Journal of Ethnic and Migration Studies 33 (6): 911-932. doi:10.1080/13691830701432756.

Koenig, M. 2015. "Governance of Religious Diversity at the European Court of Human Rights." In International Approaches to Governing Ethnic Diversity, edited by J. Bolden, and W. Kymlicka, 51-78. Oxford: Oxford University Press.

Koenig, M., and C. de Galembert. 2014. "Gouverner le religieux avec les juges. Introduction." [Governing the Religious through the Judges. Introduction]. Revue française de science politique 64 (4): 631-664. doi:10.3917/rfsp.644.0631.

Koopmans, R., and P. Statham, eds. 2010. The Making of a European Public Sphere. Media Discourse and Political Contention. Cambridge: Cambridge University Press.

Koopmans, R., P. Statham, M. Giugni, and F. Passy. 2005. Contested Citizenship. Immigration and Cultural Diversity in Europe. Minneapolis: University of Minnesota Press.

Kriesi, H. 2008. "Political Mobilisation, Political Participation and the Power of the Vote." West European Politics 31 (1-2): 147-168. doi:10.1080/01402380701834762.

Mahamood, S. 2005. Politics of Piety: The Islamic Revival and The Feminist Subject. Princeton, NJ: Princeton University Press.

Maritato, C. 2016. "Reassessing Women, Religion and the Turkish Secular State in the light of the Professional Female Preachers (Vaizeler)'s Everyday Activities in Istanbul." Religion, State and Society 44 (3). doi:10.1080/09637494.2016.1204168.

Maussen, M. 2007. "The Governance of Islam in Western Europe: A State of the Art Report." (IMISCOE Working Paper 16). http://www.euro-islam.info/wp-content/uploads/pdfs/govern ance_of_islam.pdf.

Minas, C., D. Jacobson, E. Antoniou, and C. McMullan. 2014. "Welfare Regime, Welfare Pillar and Southern Europe." Journal of European Social Policy 24 (2): 135-149. doi:10.1177/ 0958928713517917.

Modood, T. 2010. "Moderate Secularism, Religion as Identity and Respect for Religion." The Political Quarterly 81 (1): 4-14. doi:10.1111/poqu.2010.81.issue-1.

Molokotos-Liederman, L. 2016. "The Impact of the Crisis on the Orthodox Church of Greece: A Moment of Challenge and Opportunity?" Religion, State and Society 44 (1): 32-50. doi:10.1080/ 09637494.2016.1155819.

Montagut, T. 2011. "Assessing the Welfare Mix: Public and Private in the Realm of Social Welfare." In The Spanish Welfare State in European Context, edited by A. M. Guillén, and M. León, 119-138. Farnham: Ashgate.

Moreno, L. 2006. "The Model of Social Protection in Southern Europe: Enduring Characteristics?" Revue française des affaires sociales 5 (5): 73-95.

Muehlebach, A. 2012. The Moral Neoliberal. Welfare and Citizenship in Italy. Chicago: University of Chicago Press. 
O'Miel, J., and J. Talpin. 2013. "Discutere lo spazio. Come le pratiche partecipative toscane dividono la controversia rispetto alla localizzazione di una moschea a Firenze." [Discussing Space. Ho Tuscany Participatory Practices Divide the Controversy on the Mosque Localization in Florence]. Partecipazione e Conflitto 6 (3): 5-29. doi:10.3280/PACO2013-003001.

Ozzano, L., and A. Giorgi. 2016. European Culture Wars and the Italian Case. Which Side Are You On? Abingdon: Routledge.

Paternotte, D. 2008. "Les lieux d'activisme: le "mariage gai" en Belgique, en France et en Espagne." [The Space of Activism: 'Gay Marriage' in Belgium, France, and Spain]. Canadian Journal of Political Science 41 (4): 935-952. doi:10.1017/S0008423908081092.

Rétière, J.-N. 2002. "Sociohistoire de l'aide alimentaire confessionnelle à Nantes des années trente à nos jours." [A Social History of the Denominational Food Aid in Nantes from the 1930s to Nowadays]. Genèse 48 (3): 4-29.

Richardson, J. T. 2015. "Managing Religion and the Judicialization of Religious Freedom." Journal for the Scientific Study of Religion 54 (1): 1-19. doi:10.1111/jssr.2015.54.issue-1.

Robertson, R. 1995. "Glocalization: Time-Space and Homogeneity-Heterogeneity." In Global Modernities, edited by M. Featherstone, S. Lash, and R. Robertson, 25-44. London: Sage.

Rochefort, F., and M. E. Sanna, eds. 2013. Normes Religieuses et Genre. Mutations, résistances et reconfiguration XIXe - XXle siècle [Religious Norms and Gender. Mutations, Resistances and Reconfigurations XIX-XXI Centuries]. Paris: Armand Colin.

Roy, O. 2008. La sainte ignorance. Le temps de la religion sans culture [The Saint Ignorance. The Times of Religion without Culture]. Paris: Seuil.

Ruivo, F., D. Francisco, and C. Gomes. 2011. O Poder Local Português e a Construção Europeia. O Estado Labiríntico Revisitado [Portuguese Local Power and the European Construction. The Maze State Revisited]. Coimbra: Almedina.

Scotto, A. 2016. "Focusing on the Emergencies or on Their Roots? The Role of Nonprofit Organisations in Immigration Policymaking in Italy." Religion, State and Society 44 (1): 51-64. doi:10.1080/09637494.2016.1157322.

Tilly, C. 2008. Why? Princeton: Princeton University Press.

Triandafyllidou, A. 2006. "Religious Diversity and Multiculturalism in Southern Europe: The Italian Mosque Debate." In Multiculturalism, Muslims and Citizenship: A European Approach, edited by T. Modood, A. Triandafyllidou, and R. Zapata-Barrero, 117-142. Abingdon: Routledge.

Triandafyllidou, A., ed. 2009. Muslims in 21st Century Europe. Structural and Cultural Perspectives. London: Routledge.

Triandafyllidou, A., and R. Gropas. 2009. "Constructing Difference: The Mosque Debates in Greece." Journal of Ethnic and Migration Studies 35 (6): 957-975. doi:10.1080/13691830902957734.

Valasik, C. 2010. "Church-State Relations in France in the Field of Welfare: A Hidden Complementarity." In Welfare and Religion in 21st Century Europe: V. 1, Configuring the Connections, edited by A. Bäckström, G. Davie, N. Edgardh, and P. Pettersson, 129-146. Farnham: Ashgate.

Van Kersbergen, K., and P. Manow, eds. 2009. Religion, Class Coalitions and Welfare States. Cambridge: Cambridge University Press.

Vertovec, S. 2007. "Super-Diversity and Its Implications." Ethnic and Racial Studies 30 (6): 1024-1054. doi:10.1080/01419870701599465.

Wahl, É. 2008. "'J'ai eu faim, et vous m'avez nourri...' Pratiquer la charité." ['For I Was Hungry and You Gave Me Food...'. Practicing Charity]. Terrain 51: 112-129. doi:10.4000/terrain.11443.

Wohlrab-Sahr, M., and M. Burchardt. 2012. "Multiple Secularities: Toward a Cultural Sociology of Secular Modernities." Comparative Sociology 11: 875-909. doi:10.1163/15691330-12341249.

Wright Mills, C. 1940. "Situated Actions and Vocabularies of Motive." American Sociological Review 5 (6): 904-913. doi:10.2307/2084524. 